\title{
Perancangan Game First Person Shooter 3D "Saving Islamic Kingdom" dengan Menggunakan Finite State Machine (FSM)
}

\author{
Muhammad Andryan Wahyu Saputra ${ }^{1}$, Juniardi Nur Fadila², Fresy Nugroho ${ }^{3}$ \\ Jurusan Teknik Informatika, Fakultas Sains dan Teknologi1,2,3 \\ Universitas Islam Negeri Maulana Malik Ibrahim \\ 118650030@student.uin-malang.ac.id, 2juniardi.nur@gmail.com, \\ 3fresysss@gmail.com
}

\begin{abstract}
Video Game is a game with a visual or image manifestation that can give back reactions to the user if given certain commands contained in the electronic system control device. Many technological innovations can be applied in a game, one of which is the application of artificial intelligence. One of the game variations that will be applied is the First Person Shooter (FPS) game. First Person Shooter (FPS) game is one type of game that is often played using firstperson observation where the player is the main character in the game. The artificial intelligence developed by applying the finite state machine (FSM) functions to see the behavior of the Non Player Character (NPC) or the enemy to attack the main player. The results of this study are that the game Saving Islamic Kingdom provides artificial intelligence results on the behavior of the Non Player Character by implementing the Finite State Machine (FSM) algorithm so that the enemy can behave in accordance with the instructions made by the player.
\end{abstract}

Keyword : $\quad$ First Person Shooter, Game, Unity 3D, Finite State Machine.

\begin{abstract}
Abstrak
Video Game merupakan sebuah permainan dengan manifestasi sebuah visual atau gambar yang dapat memberikan reaksi balik kepada pengguna jika diberikan perintah - perintah tertentu yang terdapat pada alat kontrol sistem elektronik. Banyak inovasi teknologi yang dapat diterapkan dalam sebuah game salah satunya penerapan kecerdasan buatan atau artificial intelligence. Variasi game yang akan diterapkan salah satunya adalah game First Person Shooter (FPS). Game First Person Shooter (FPS) merupakan salah satu jenis game yang sering dimainkan menggunakan pangamatan orang pertama di mana player sebagai karakter utama dalam game. Kecerdasan buatan yang dikembangkan dengan menerapkan Finite State Machine (FSM) berfungsi untuk melihat respon perilaku Non Player Character (NPC) atau musuh untuk menyerang pemain utama. Hasil dari penelitian ini adalah game Saving Islamic Kingdom memberikan hasil kecerdasan buatan pada perilaku Non Player Character dengan mengimplementasikan algoritma Finite State Machine (FSM) sehingga musuh atau NPC dapat berperilaku sesuai dengan intruksi yang dilakukan oleh player.
\end{abstract}

Kata Kunci: $\quad$ First Person Shooter, Game, Unity 3D, Finite State Machine.

http://journal.walisongo.ac.id/index.php/jit/index WJIT : Walisongo Journal of Information Technology 


\section{PENDAHULUAN}

Globalisasi telah menyebabkan berkembang pesat-nya teknologi, teknologi telah menjadi bagian inti dari kehidupan masyarakat kita. Berkembang teknologi juga berdampak pada berkembang media informasi kita, dari media cetak berkembang menjadi media digital. Teknologi komputer saat ini bukan berbentuk PC (Personal Computer), namun tablet hingga smartphone sudah menggunakan teknologi yang berasal dari PC (Personal Computer). Komputer tidak hanya dikenal oleh masyarakat sebagai media yang digunakan untuk memudahkan dan mempercepat pekerjaan, namun masyarakat kini menggunakannya untuk belajar danx berbelanja serta bermain.

Game berjenis First Person Shooter atau disingkat FPS adalah jenis game perang menggunakan senjata dengan pandangan orang pertama melalui aktualisasi layar sesuai dengan apa yang dilihat oleh player yang memainkannya. Game berjenis FPS dipilih dikarenakan permainan ini sangat disukai dan diminati sampai sekarang, hal ini disebabkan dari penilaian yang tinggi dan analisis yang diberikan para atlet e-sport atau gamers.

Game dengan grafik 3D adalah game dengan kualitas baik seperti dengan realita yang ada, akan tetapi dalam memainkan game 3D, komputer atau smartphone disarankan memiliki spesifikasi yang tinggi agar tampilan 3D dapat ditampilkan dengan sempurna.
Awal kemunculan game hingga sekarang sudah banyak menggunakan kecerdasan buatan, dikarenakan dengan adanya kecerdasan buatan dalam pembuatan game dapat membuat jalan cerita di dalam game menjadi semakin hidup dan tidak membosankan. Kecerdasan Buatan pada game First Person Shooter biasanya terdiri atas perencanaan path, mengambil item, menggunakan item, dan berperang(Asmiatun \& Hendrawan, 2016). Pada game Saving Islamic Kingdom ini menggunakan Finite State Machine (FSM) untuk melihat perilaku karakter non player atau musuh sesuai interaksi yang dilakukan player.

\section{METODE PENELITIAN 2.1 Penentuan Konsep}

Tahap pertama adalah tahapan untuk menentukan konsep game yang akan dikembangkan (Astuti et al., 2019). Game ini bernama "Saving Islamic Kingdom", yaitu game single player game yang hanya dimainkan oleh satu orang saja. Player harus membidik dan menembakkan senjatanya ke arah musuh. Pada game ini nantinya akan dirancang perilaku Non Player Character (NPC) dengan kecerdasan buatan menggunakan metode Finite State Machine.

Inti dari konsep diatas adalah sebagai berikut :

1. Grafik game 3D

2. Merancang perilaku NPC

3. Sistem Single Player

4. Kontrol play menggunakan mouse dan keyboard 
Perancangan Game First Person Shooter 3D "Saving Islamic Kingdom" dengan Menggunakan Finite State Machine (FSM)

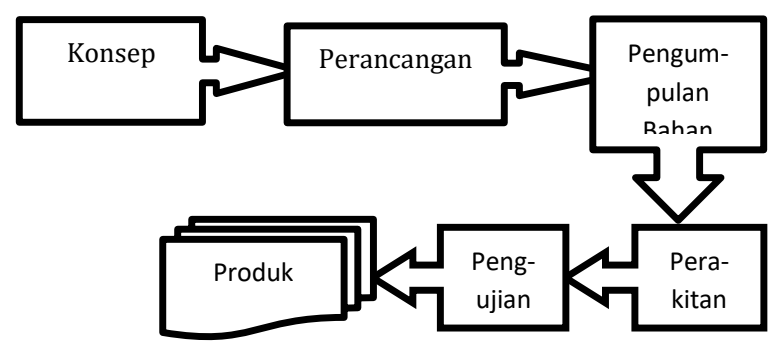

Gambar 1 Tahap-Tahap

Penelitian Metode Research and Development

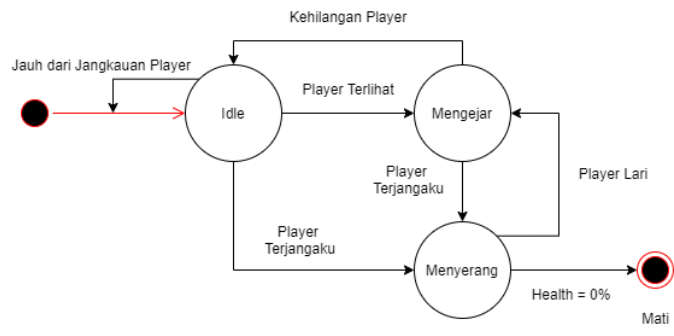

Gambar 2 Rancangan FSM NPC Musuh

\subsection{Perancangan}

Tahap ini merupakan tahapan mendesain atau merancang game yang akan dikembangkan.

a. Perancangan Gameplay Penyerangan dilakukan dengan cara berjalan dengan menekan tombol keyboard W, kemudian tombol keyboard A untuk berjalan ke kiri, tombol keyboard D untuk berjalan ke kanan, tombol keyboard S untuk berjalan mundur, tombol shift untuk berlari dan tombol spasi untuk lompat dan klik kiri pada mouse untuk shoot (menembak musuh). Nyawa player dapat berkurang jika player terkena serangan dari musuh dan peluru juga berkurang ketika player menembakkan senjatanya. Nyawa player dapat bertambah jika player berhasil menemukan kotak berwarna hijau dan amunisi dari senjata bisa bertambah jika player berhasil menemukan kotak berwarna coklat. Kotak - kotak tersebut tersebar di dalam hutan dalam game ini.

b. Perancangan Kecerdasan Buatan NPC Musuh

Penjelasan

Rancangan

Kecerdasan Buatan NPC Musuh :

1. Patroli : Game dimulai dan musuh berpatroli atau berjalan jalan saat jauh dari jangkauan player.

2. Mengejar : Saat player terlihat dan dekat dengan jangkauan serang musuh maka musuh akan mengejar player.

3. Menyerang : Saat player terjangkau oleh musuh maka musuh akan menyerang player. Saat player lari musuh berpindah ke posisi mengejar.

4. Mati : Player akan mati jika kesehatan player mencapai $0 \%$.

\subsection{Skenario Perubahan Perilaku Pada NPC Musuh}

Dibuat skenario untuk game ini yang dijadikan simulasi atau uji coba dalam perubahan perilaku NPC musuh (Arif et al., 2011). Karakter dibagi menjadi dua bagian, yaitu pemain utama (player) dan NPC musuh yang dijadikan obyek dalam penelitian ini. NPC musuh mempunyai perilaku menyerang sekaligus 
variabel yang mempengaruhi perubahan pada perilaku seperti pada tabel dibawah ini yaitu skenario respon NPC musuh idle, mengejar dan menyerang.

Tabel 1 Skenario Perubahan Perilaku Pada NPC Musuh

\begin{tabular}{|c|c|c|}
\hline NPC & $\begin{array}{c}\text { Variabel } \\
\text { Input } \\
\text { Perilaku }\end{array}$ & $\begin{array}{c}\text { Variabel } \\
\text { Output } \\
\text { Perilaku }\end{array}$ \\
\hline NPC & $\begin{array}{c}\text { Jarak } \\
\text { terhadap } \\
\text { player }\end{array}$ & $\begin{array}{c}\text { Idle, } \\
\text { mengejar } \\
\text { player, } \\
\text { Menyerang } \\
\end{array}$ \\
& & $\begin{array}{c}\text { Mener } \\
\text { player }\end{array}$ \\
\hline
\end{tabular}

\subsection{Pengumpulan Bahan}

Bahan-bahan yang diperlukan dalam pembuatan game ini adalah animasi, environment hutan, objek istana kerajaan Islam, tekstur, material, musik, gambar, dan sebagian diperoleh melalui internet dengan mendownload asset dari unity3D yaitu asset game FPS berupa controller player, gambar, audio, dan software Unity 3D versi 2019.4.9.f1.

\subsection{Perakitan}

Tahap perakitan adalah tahapan menyusun dan mengatur bahanbahan yang digunakan untuk pengembangan game sehingga menjadi game yang mengimplementasikan kecerdasan buatan untuk mengatur perilaku musuh. Bahasa pemograman C\# digunakan untuk mengimplementasikan Finite State Machine (FSM) pada perilaku musuh di dalam perakitan game ini.
Kemudian bahasa pemograman ini digunakan untuk mengontrol setiap objek game dan interaksi player seperti berlari, menembak serta seluruh animasi pada karakter musuh. Berikut adalah gambar screenshoot di Unity3D saat proses perakitan yang dapat dilihat pada gambar 3 .

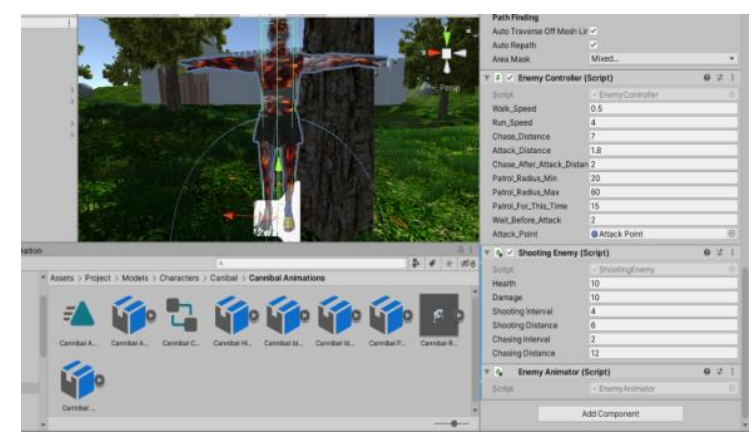

Gambar 3 Tahapan perakitan

\subsection{Pengujian}

Pengujian dilakukan dengan menggunakan black box testing secara keseluruhan pada perilaku NPC musuh, apakah dapat menghasilkan keragaman respon perilaku musuh dengan menerapkan metode Finite State Machine (FSM) berdasarkan intruksi yang dilakukan oleh player.

\section{KERANGKA TEORI}

\subsection{Game}

Dalam jurnal yang ditulis oleh Robert Theophani Singkoh (2016) dijelaskan bahwa pengertian game adalah suatu kegiatan penyelesaian masalah, mendekati sikap menyenangkan, dengan game membuat pemain dapat menemukan kesenangan dan tidak jenuh dalam memainkannya. Game harus bisa membuat pengguna terlibat aktif dan 
Perancangan Game First Person Shooter 3D "Saving Islamic Kingdom" dengan Menggunakan Finite State Machine (FSM)

mempunyai jumlah tantangan atau tingkat kesulitan tidak terlalu banyak atau terlalu sedikit (Singkoh et al., 2016).

\subsection{Sejarah Game}

Pada tahun 1963 game pertama diciptakan oleh Steve Russel yang merupakan ilmuwan dalam bidang ilmu komputer yang berasal dari Amerika. Steve Russel menciptakan game Spacewar lalu dikembangkan oleh Martin Graetz, Dan Edwards, dan Pete Simson. Dari sini masyarakat dapat merubah anggapan komputer yang hanya untuk bekerja.

Seseorang berkebangsaan Jerman yang tinggal di Amerika berhasil membuat sebuah permainan televisi pada tahun 1966 di perusahaan bernama Sanders, dia adalah Ralph $\mathrm{H}$. Baer. Kemudian dikembangkan yang akhirnya menjadi konsol game yang bernama Brown Box dan diselesaikan tahun 1986. Kontrol pistol untuk video game yang pertama kali di dunia dibuat oleh Ralph juga dan bisa dimainkan di televisi.

\subsection{Jenis jenis Game}

\section{- Action Game}

Action game merupakan game dengan model pertarungan. Berikut ini contoh dari action game yaitu Beat'em up Game,Stealth Game, Fighting Game, Action Adventure Game, Paltform Game, Maze Game, dan Game Penembak yang terbagi atas Third-Person Shooter, First-Person Shooter, Game, Game Tactical, Lightgun Game, dan Shooter Game. (Singkoh et al., 2016)

\section{- Adventure Game}

Jenis game ini adalah game yang mengharuskan player menyelesaikan berbagai macam puzzle dengan hubungan dalam lingkungan di game tersebut. Game Adventure ini terbagi atas Graphical Adventure Game, Text Adventure Game/Interactive Fiction Game, Visual Novel Game, Dialog Game, dan Interactive Movie Game. (Singkoh et al., 2016)

\section{- Role-Playing Game}

Role Playing Games atau RPG adalah jenis game dimana player mempunyai karakter yaitu berpetualang mempunyai mode permainan di mana player memiliki karakter akan berpetualang dengan skill bertarung dalam ceritanya. Role Playing Game terbagi atas Tactical Role Playing Game, Massively Multiplayer, Action Role Playing Games. (Singkoh et al., 2016)

\section{- Simulation Game}

Jenis Game ini bertujuan untuk memberikan pengalaman kepada pemain melalui simulasi. Construction and management simulation Game (CMSs) merupakan game yang mengharuskan player memperluas, mendirikan, dan mengelola bangunan fiksi. Game berjenis ini terbagi menjadi Economic-Simulation Game, City Building Game, Government Simulation Game, and God Game.

\section{- Strategy Game}

Untuk memenangkan permainan ini dibutuhkan pemikiran dan strategi yang tepat. Strategy Game terbagi atas Turn-Based Strategy Game, Tactical 
Game, and Real-Time Strategy. (Singkoh et al., 2016)

\subsection{Aplikasi yang digunakan}

\section{- Blender}

Aplikasi Blender adalah sebuah perangkat lunak (software) yang open source atau gratis yang dipergunakan untuk membuat modeling 3D, rigging, texturing, camera tracking, fluid, efek visual, video editing, smoke simulasi, rendering, dan film animasi serta memiliki game engine untuk pembuatan game. (Singkoh et al., 2016)

Dalam perancangan game ini software Blender digunakan untuk membuat asset dan environment.

\section{- Unity}

Perangkat lunak atau software unity 3D merupakan game engine yang digunakan sebagai pembuatan video game, pengolah gambar, grafik, input, suara, dan lain-lain yang biasanya ditujukan untuk membuat game, tetapi bisa digunakan selain membuat game. Contohnya materi pembelajaran untuk pelayanan masyarakat. Kelebihan dari aplikasi Unity 3D ini adalah dapat membuat game berdasar 3D maupun 2D, dan unity mampu mencetak menjadi game Android, IOS, berbasis website, XBOX, dan PS3. (Singkoh et al., 2016)

\subsection{Finite State machine (FSM)}

Finite state machine (FSM) adalah sebuah prosedur perancangan sistem kontrol yang menjelaskan prinsip kerja sistem atau tingkah laku dengan menggunakan tiga kondisi berikut: State (Keadaan), event (kejadian) dan action (aksi). Sistem pertama tama akan berada pada salah satu keadaan atau state yang aktif. Sistem dapat bertransisi atau berubah menuju state lain jika mendapatkan kejadian atau masukan tertentu, baik masukan tersebut dari luar atau dalam sistem itu sendiri dalam waktu yang cukup signifikan. Perubahan keadaan ini biasanya diikuti oleh aksi yang dilakukan oleh pengguna atau sistem ketika merespons masukan atau kejadian yang terjadi. Respons yang dilakukan tersebut melibatkan rangkaian proses yang relatif kompleks atau dapat berupa aksi yang sederhana (Rahadian et al., 2016).

\subsection{Analisis Pembuatan Game}

Pendekatan yang dilakukan dalam penelitian perancangan game ini adalah menggunakan metode penelitian pengembangan (Research \& Development). Menurut Sugiyono (2010:407), dengan metode penelitian pengembangan ini akan digunakan untuk melahirkan produk tertentu (Purnama, 2013).

\section{PEMBAHASAN}

\subsection{Hasil implementasi Finite State Machine}

Implementasi Finite State Machine pada game Saving Islamic Kingdom, jika jarak antara player dan musuh > 20 maka musuh akan berada di state idle, jika < 20 maka musuh akan mengejar player, dan saat jarak $<1$ maka musuh akan menyerang player. 
Perancangan Game First Person Shooter 3D "Saving Islamic Kingdom" dengan Menggunakan Finite State Machine (FSM)

Berikut ini merupakan hasil implementasi Finite State Machine :

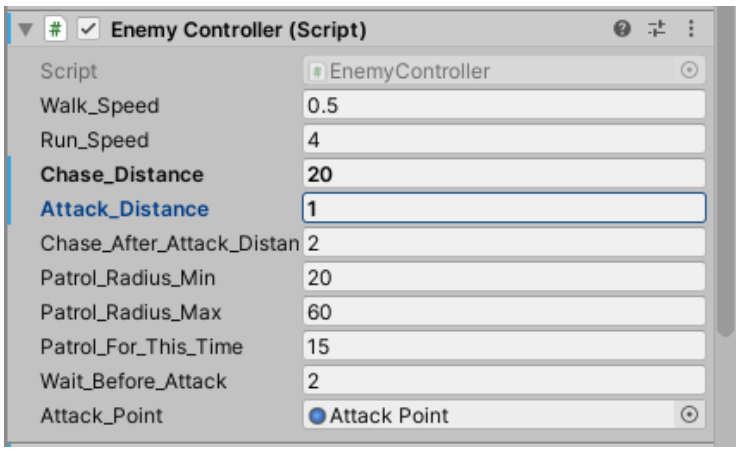

Gambar 4 Implementasi Finite State Machine

- Musuh Patroli

Keadaan musuh berpatroli dimana jarak antara player dan musuh berada lebih dari 20 .

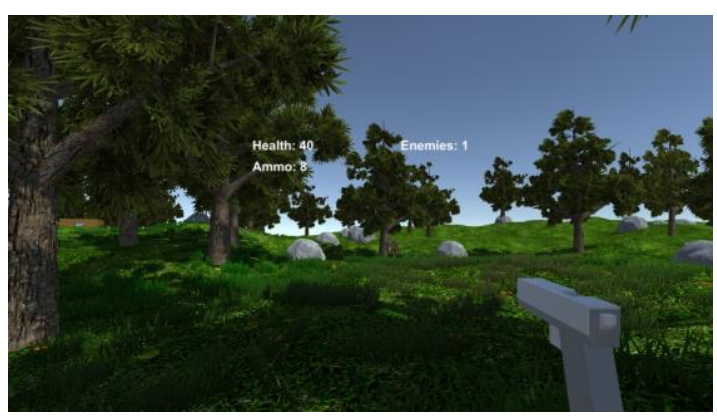

Gambar 5 Musuh Berpatroli

- Musuh Mengejar

Keadaan ketika jarak antara player dengan musuh kurang dari 20, maka musuh otomatis akan mengikuti player.

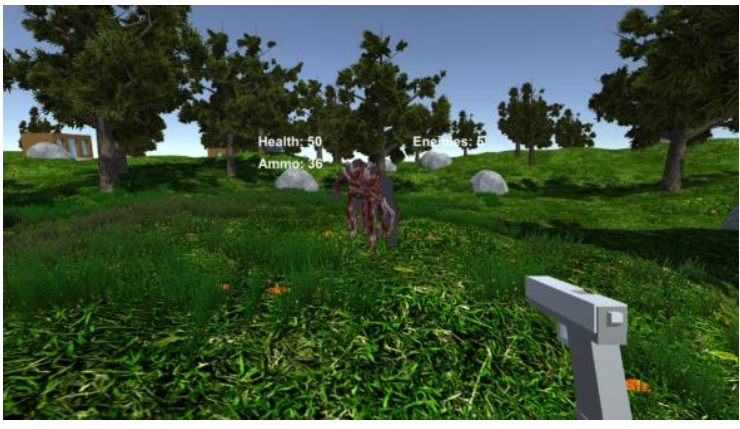

Gambar 6 Musuh Mengejar

Player

- Musuh Menyerang

Keadaan dimana jarak antara player < 1 sehingga musuh akan berperilaku menyerang player yang sudah berada dekat sekali dengan radius serang musuh.

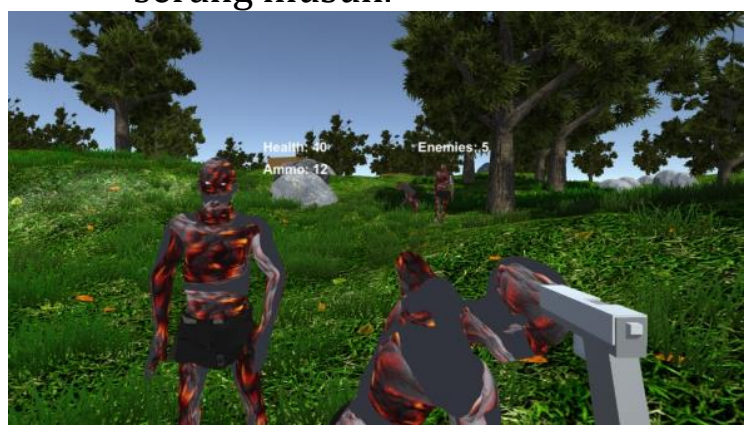

Gambar 7 Musuh Menyerang Player

\subsection{Layout dan Segmen Program}

\subsubsection{Menu utama}

Didalam menu utama terdapat 3 tombol yaitu tombol Mulai yang mengarahkan pemain untuk memulai permainan, tombol Bantuan, dan tombol Keluar permainan. Berikut adalah tampilan menu utama : 


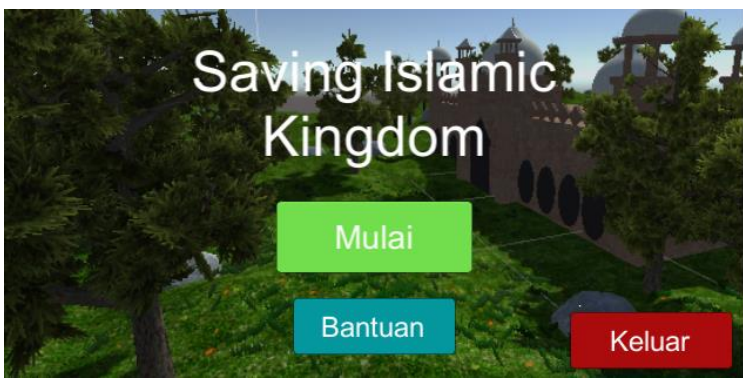

Gambar 8 Menu utama

\subsubsection{Menu Bantuan}

Menu Bantuan merupakan menu yang berisi informasi tentang bagaimana jalannya permainan dan kontrol permainan menggunakan keyboard dan mouse.

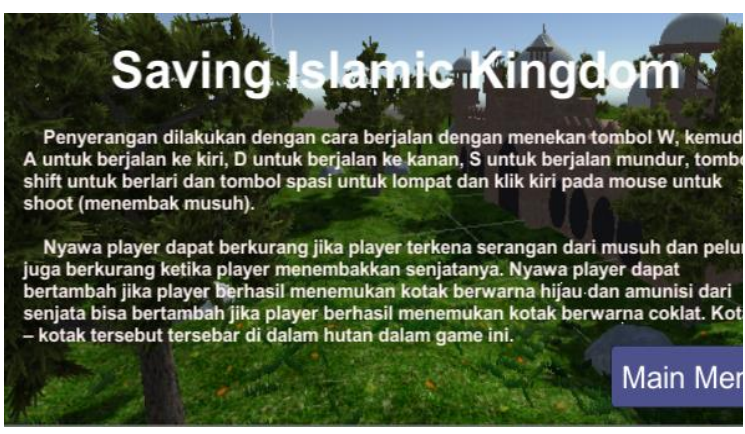

Gambar 9 Menu Bantuan

\subsubsection{Menu Pause}

Menu Pause akan tampil kerika player menekan tombol "esc" pada keyboard dimana permainan masih berlangsung dan menghentikan permainan untuk sementara. Dalam Menu Pause berisi tombol "Resume" untuk kembali ke permainan", tombol "Bantuan" berisi informasi control permainan, dan tombol "Keluar" untuk keluar dari permainan menuju Main Menu.

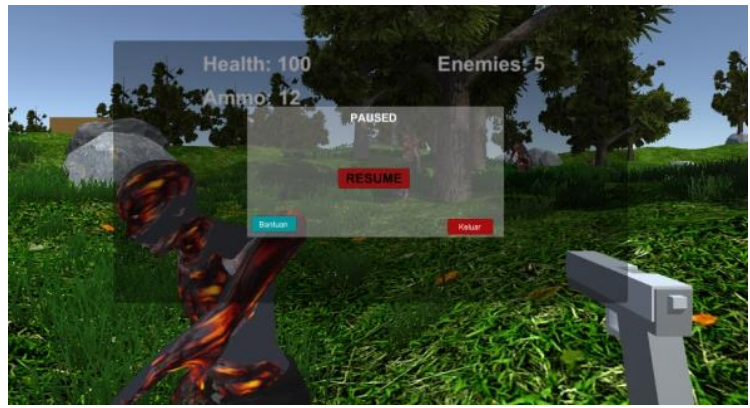

Gambar 10 Menu Pause

\subsubsection{Tampilan Awal Game}

Pada tampilan awal ini player diharuskan untuk menjaga istana atau kerajaan dari serangan musuh dengan cara menembakkan peluru ke arah musuh.

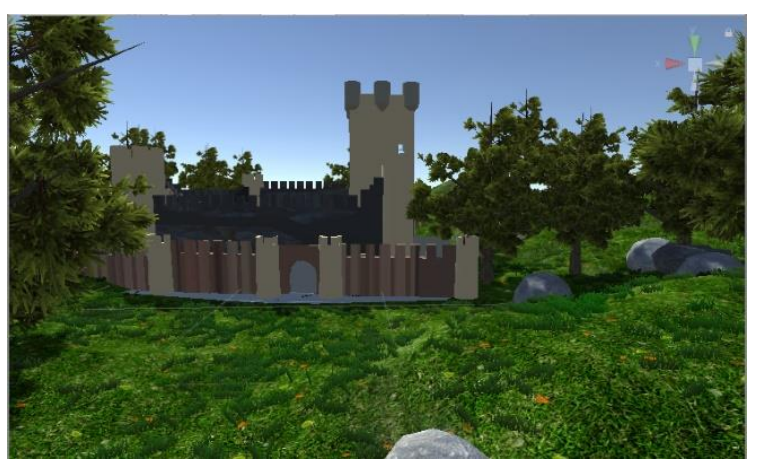

Gambar 11 Tampilan Awal Game

\subsubsection{Tampilan Menembak Musuh}

Pada tampilan ini player mangarahkan senjatanya ke arah musuh lalu menekan klik kiri pada mouse untuk melepaskan peluru, jika musuh terkena peluru maka musuh akan mati dan jumlah dari enemies akan berkurang. 
Perancangan Game First Person Shooter 3D "Saving Islamic Kingdom" dengan Menggunakan Finite State Machine (FSM)

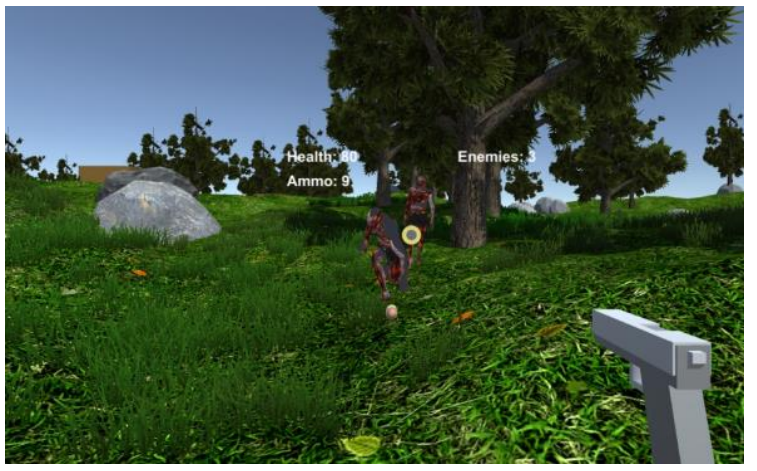

Gambar 12 Tampilan Menembak Musuh

\subsubsection{Tampilan Help Box}

Pada tampilan ini player berhasil menemukan kotak bantuan yaitu kotak berwarna hijau dan kotak berwarna coklat. Dimana kotak berwarna hijau dapat menambah nyawa atau kesehatan player dan kotak berwarna coklat untuk menambah amunisi dari senjata player. Kotak - kotak tersebut tersebar di dalam hutan dalam game ini. Sehingga membuat game ini lebih hidup dan menarik serta memberikan tantangan kepada player untuk menemukan kotak tersebut.

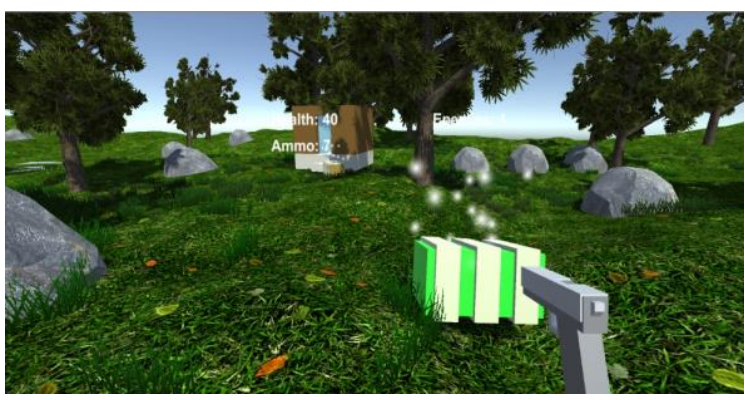

Gambar 13 Tampilan Help Box

\subsubsection{Tampilan Lose Scene}

Tampilan ini akan muncul jika darah atau nyawa player habis, maka player diberikan pilihan untuk mengulangi game atau menuju main menu.

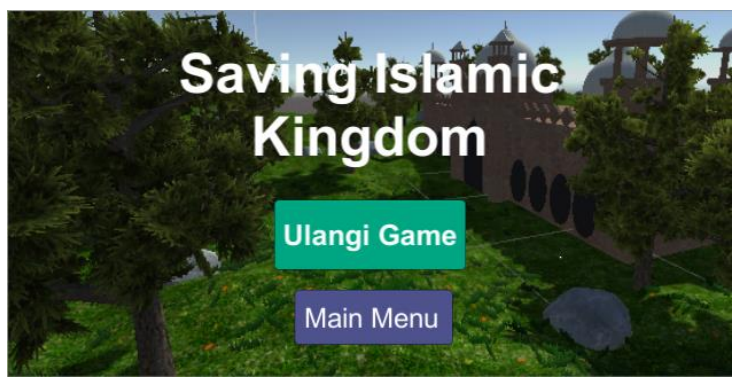

Gambar 14 Tampilan Lose Scene

\subsubsection{Tampilan Win Scene}

Tampilan ini akan muncul jika player berhasil membunuh semua musuh dan player dapat melanjutkan ke level berikutnya dengan jumlah musuh yang lebih banyak.
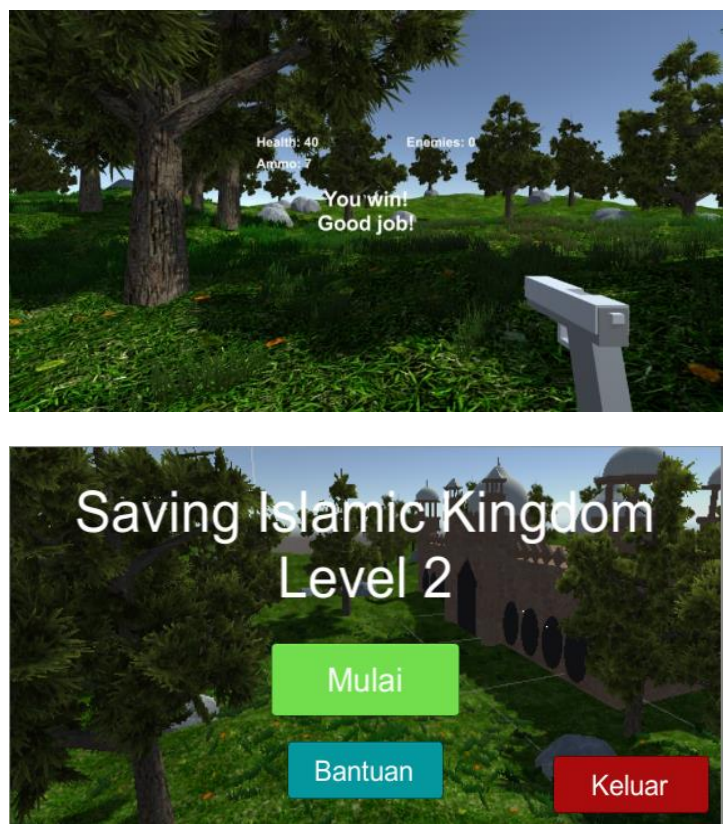

Gambar 15 Tampilan Win Scene 


\section{PENUTUP}

Berdasarkan penelitian yang dilakukan diperoleh simpulan sebagai berikut

Berdasarkan hasil dan pembahasan pada implementasi metode Finite State Machine (FSM) dalam perilaku musuh dapat disimpulkan bahwa game Saving Islamic Kingdom menghasilkan kecerdasan buatan pada perilaku musuh dengan mengimplementasikan metode finite state machine sehingga menghasilkan respon musuh yang berbeda menyesuaikan masukan yang diberikan oleh player. Beberapa respon NPC yang terjadi yaitu, respon saat musuh melihat player dan berada di jangkauan serang musuh maka musuh akan bergerak mengejar kearah player lalu menyerangnya dan musuh akan mati jika terkena tembakan dari player.
Hasil implementasi pada game ini harus terus dikembangkan dan disempurnakan. Maka dari itu ada beberapa saran untuk mengembangkan dan menyempurnakan game berjenis First Person Shooter (FPS) pada Game Saving Islamic kingdom berupa penambahan jenis senjata dan level pada game, lalu menambahkan perilaku menyerang musuh, menambahkan asset dan environment serta latar tempat yang lebih realistis sehingga permainan akan jauh lebih menarik dan membuat player tidak mudah bosan. Menambahkan 2 atau 3 lagi jenis musuh dan keahlian menyerangnya dalam sebuah tim, sehingga dapat terciptanya strategi baru yang lebih menarik dengan memberikan tindakan atau respon yang berbeda-beda pada setiap NPC. 
Perancangan Game First Person Shooter 3D "Saving Islamic Kingdom" dengan Menggunakan Finite State Machine (FSM)

\section{REFERENCES}

Arif, Y. M., Kurniawan, F., \& Nugroho, F. (2011). A2-18 - YUNIFA_MISTACHUL_ARIF - DESAIN PERUBAHAN PERILAKU.pdf. In Seminar On Electrical, Informatics, and Education 2011 (pp. 1-8).

Asmiatun, S., \& Hendrawan, A. (2016). Implementasi Klasifikasi Bayesian Untuk Strategi Menyerang Jarak Dekat Pada Npc (Non Player Character)Menggunakan Unity 3D. Jurnal Transformatika, 13(2), 42. https://doi.org/10.26623/transformatika.v13i2.139

Astuti, Y. W., Yunus, A., \& Ahsan, M. (2019). Perilaku Non Player Character ( Npc ) Pada Game Fps “ Zombie Colonial Wars " Menggunakan Finite State Machine ( Fsm ). Jurnal Teknologi, Informasi Dan Industri, 2(2016), 53-63.

Purnama, S. (2013). Produk Pembelajaran Bahasa Arab. Literasi, 4(1), 19-32.

Rahadian, M. F., Suyatno, A., \& Maharani, S. (2016). Penerapan Metode Finite State Machine Pada Game "The Relationship." Informatika Mulawarman: Jurnal Ilmiah Ilmu Komputer, 11(1), 14. https://doi.org/10.30872/jim.v11i1.198

Singkoh, R. T., Lumenta, A. S. M., \& Tulenan, V. (2016). Perancangan Game Fps (First Person Shooter) Police Personal Training. Jurnal Teknik Elektro Dan Komputer, 5(1), 28-34. https://doi.org/10.35793/jtek.5.1.2016.11490 
Muhammad Andryan Wahyu Saputra ${ }^{1}$, Juniardi Nur Fadila ${ }^{2}$, Fresy Nugroho ${ }^{3}$

This page intentionally left blank. 